膠芽腫はなぜ難治なのか？一克服への可能性一

植木 敬介

獨協医科大学脳神経外科・総合がん診療センター

\title{
Untying the Gordian Knot: Why Glioblastomas are Still Incurable, and How Can We overcome the Hurdles
}

\section{Keisuke Ueki, M.D.}

Department of Neurologic Surgery, Dokkyo Medical University, Dokkyo Medical University Hospital Comprehensive Cancer Center

We are currently observing a plethora of new anti-cancer drugs which represent the fruits of extensive cancer research conducted over the past several decades. Some of these novel drugs can help achieve practical cure in hitherto deadly cancers. On the other hand, the prognosis of glioblastoma still remains one of the worst. This may be a good time to reflect on the reasons and the underlying mechanisms of such poor prognoses in glioblastomas. Some of the obvious reasons include the location, the highly invasive nature, and resistance to radiation, chemotherapy, and immunotherapy. Several novel therapeutic strategies are being developed to overcome these obstacles. Here we analytically summarize this topic.

(Received November 27, 2019; accepted December 26, 2019)

Key words : glioblastoma, treatment

Jpn J Neurosurg（Tokyo）29：198-203, 2020

\section{はじめに}

すべての悪性腫瘍の中でも, 膠芽腫（glioblastoma）は 最も難治で予後の悪い “脳の癌（brain cancer)”として 一般にも知られている。他の癌に比べれば頻度は少ない ものの，米国の John McCain 上院議員や Edward Kennedy 上院議員などの著名人が, “brain cancer-glioblastoma”の ために短い闘病生活の末に亡くなったことでも最近また 注目を浴びた。䯣芽腫や胚細胞腫などの他の悪性脳腫瘍 においては, 過去 30 年ほどの間で予後が著明に改善し てきたものもあるが, 膠芽腫の治療と予後はそれに比べ ると改善がそしい.ここでは, 膠芽腫がなぜ難治なのか, その克服への展望はどうなっているのかの現状を分析,
提示してみる。

\section{「治癒」が難しいのは膠芽腫だけではない}

「難治」という言葉は文字どおり治癒が難しいというこ とであるが，冷静に考えればこれは膠芽腫だけでなく， びまん性神経膠腫全体にいえることである. 2016 年に更 新された WHO 分類では, びまん性神経膠腫の診断に遺 伝子変異の情報が取り入れられたが，この分類において 最も予後がよい IDH 変異 $(+) \cdot 1 \mathrm{p} / 19 \mathrm{q}$ 共欠失を示す乏 突起膠腫でさえ，10 年生存率は $50 \%$ に届いておらず, 「治癒」できているわけではない1)。一方, IDH 変異 $(-)$ の膠芽腫の 5 年生存率は数\%, 10 年生存率はほぼゼ口 
で, あらゆる癌の中でも確かに最も予後が悪い. 開き直 るようだが，現時点でそのような悪性腫瘍に「治癒」と いう言葉はほぼ現実的ではない目標にみえる。では，現 実的な目標はというと, 診断, 治療にさまざまなイノ ベーションを導入することで, 生存率を少しずつ, しか し明確に改善していくことであろうと思わ机る。

\section{治癒に至る道とは？}

「治癒」と宣言できる状態とは，2つのパターンがあ る. 1 つは腫瘍細胞がすべて体内からなくなることで, 早期癌の完全摘出や強力な化学療法, あるいは免疫系の 働きを通じて達成される可能性がある。もう 1 つは, 腫 瘍の増殖がきわめて長い間にわたって抑制される場合で ある．腫瘍細胞が残っていても構わないが，それが人の 自然な寿命に相当する時間, 何も症状を出さない程度に 増殖抑制されれば，実用的な意味では「治癒」と同じこ とである。このようなパターンの典型例は慢性骨髄性白 血病 (chronic myelogenous leukemia: CML) である. BCR-ABL チロシンキナーゼを選択的に阻害するイマチ ニブ（Gleevec）を投与し続けることで，9割以上の確率 でほぼ完全に腫瘍の増殖を抑えることができるように なった，薬を中止すれば再燃するので, 腫場細胞はなく なったわけではないが，投与を続けていれば，治癒して いるのと同じである.

膠芽腫においても「治癒」を目指すのであればこの 2 つのうちどちらかの目標を達成しなければならない。 そ れを困難にしている理由を整理してみることは大事であ る。

\section{外科治療の挑戦}

膠芽腫がきわめて浸潤性の高い腫瘍であること,さら には肉眼的に異常と思われる領域の摘出では再発を免れ ないことは早くから知られていた。現在の標準的手術は “可及的最大摘出 (maximal safe resection)” であるが, 過去にはもっと積極的な摘出が試みられている. Dandy $^{3)} 1923$ 年に, すでに左片麻痺を呈している膠芽 腫と思われる患者 5 例に対して半球切除 (hemispherectomy）を施行した報告をしているが, すべて 3 年以内に 再発で死亡し, 外科手術での治癒が難しいことを示して いる. 1933 年には Gardner ${ }^{5)}$ が glioma に対して hemispherectomy を行い, 長期再発を防いだことを報告して いるが，この腫瘍の組織は典型的な oligodendroglioma で，おそらく 1p/19q co-deletionを有するものと思われ
る。もともと長期生存が期待できるこの腫瘍に hemispherectomy を行うことは, 現在の医療としては許され ない. 1961年には後に熊本大学の学長になられた松角先 生が Mayo Clinic において grade III, IVの astrocytoma 100 例の剖検脳を検討し，16 例で脳幹や視床の主座，32 例で 反対側の大脳半球に浸潤，さらに 16 例では脳幹や視床 に浸潤が認められ，拡大手術の適応はない患者であった と報告している。優位半球の手術は不可能であることを 考えると, 半球切除の意味がありそうなのは $20 \%$ 以下 で，それも重大な神経症状を覚悟しなければならないと いう結論を述べている7).このような歴史を経て, 膠芽 腫に対する究極の積極手術である半球切除は適応がな い，というコンセンサスに至っている.

一方で, ナビゲーション, 術中 MRI, 覚醒下手術など のさまざまな技術によって, 膠芽腫の摘出を安全な範囲 で最大化する試みが過去 20 年ほどの間に進められた。 2011 年には MRI で造影される部分 (contrast-enhancing lesion）を摘出できた割合と生命予後の相関をみると, 摘 出率 $90 \% ， 95 \% ， 98 \% ， 100 \%$ と徐々に予後がよくなつ ているというS Sanai ら ${ }^{11)} の$ 論文が発表された。手術摘出 と予後の相関をみたこのような研究はランダム化された 試験ではないので，常にバイアスの問題はあるが，この ような結果に基づいて, 手術の目標は,「可能ならば造影 病変の $100 \%$ 摘出」というのがコンセンサスになってい る.一方, $100 \%$ 摘出できた症例でも 3 年生存率は $10 \%$ で，治癒するわけではないことは明らかである。近年で は，造影病変を超えた “supra-total resection”を追求す るというグループがみられるようになり, 再び aggressive surgical resectionの方向へ向かっている感もあるが, 一定の予後改善に寄与する可能性はあるが, 「治癒摘出」 という点からは先に述べたように「いつか来た道」であ り，外科治療の積極化のみで「治癒」を目指すのは不可 能といわざるを得ない.

\section{術後療法に対する抵抗性のメカニズム}

外科的な摘出で治癒が望めない以上, 術後の残存腫瘍 に対する治療で治癒を追求するしかない. 現在は放射線 治療と化学療法がその術後治療の主体になっている。し かし，膠芽腫はこれらにも抵抗性が高く，腫瘍細胞をゼ ロにすることはできていない.

「抵抗性」には 2 つタイミングがある。1つは最初か ら完全には効かないという初期抵抗性（primary resistance）で, もう1つは, 最初は効果があるが新たな抵抗 性のメカニズムを獲得して再発する, 獲得抵抗性 
(acquired resistance）である.

膠芽腫における primary resistance のメカニズムとし て提唱されているのはグリオーマ幹細胞の存在と, それ を支える微小環境 (niche) の存在である. グリオーマ幹 細胞についてはここでは詳細に述べないが, 要するに膠 芽腫を構成している腫瘍細胞の一部に, (1)神経幹細胞に 類似したような未分化な状態を維持し, (2)ゆっくりと分 裂し，(3)さまざまな薬物の作用に抵抗性を示す性質をも ち, (4)1個の細胞から多彩な組織形態を有する腫瘍を形 成し得る, という細胞が一定数存在し, これが再発の原 因になるという理論である。このような細胞が維持され るための環境が niche と呼ばれる環境で, 低酸素状態や $\mathrm{TGF} \beta$ の活性などが条件として提唱されている ${ }^{13)}$.

\section{放射線治療の挑戦}

術後初期治療で腫瘍細胞をゼロに近づけるためには, 治療強度を上げるというのが最も明快なやり方である. 当然, 正常脳に対する障害を防ぎながら, ということに なり, 多分割照射や高精度照射などさまざまな照射法が 試みられてきたが有効な結果は出ていない。ささらに東京 大学のグループは 80〜90 Gy の強力な照射を試みたが, 結果は生命予後の改善はなく, 副作用のみが強くなっ て, この方法も頓挫した ${ }^{16)}$. 広く浸潤する腫瘍をすべて 高線量で治療することは, 通常の照射ではやはり限界が ある. 1951年に初めて脳腫瘍に行われたホウ素中性子補 足療法（boron neutron capture therapy：BNCT）は, 正常 細胞にはほとんど影響がない，という理論の下に行われ たが，やはり副作用は大きく，いったん諦められていた が, 投与するホウ素化合物の改良などを経て, 近年再び 日本を中心に臨床治験が行われている ぞおりに腫瘍細胞を選択的に殺傷できるか, どの程度深 部の病変に到達できるかがポイントで, その成否はここ にかかっていると思われる。

\section{化学療法の挑戦}

悪性腫瘍の化学療法・薬物療法は, 近年急速に進歩が みられている分野であるが, 膠芽腫に関していえば，そ の生命予後に関する効果が明確に示されているのは 2006 年に保険収載されたテモゾロミドだけである. 血管 新生阻害剤のベバシズマブは腫瘍血管を正常化させるこ とによって浮腫の減少, 症状緩和には有効であるが, お そらく腫瘍細胞を殺傷する効果はなく, 生命予後は改善 しないことが知られている。したがって, 現時点で「化
学療法抵抗性」という場合は,「テモゾロミド抵抗性」と ほぼ同義であるといってもいい.

Primary resistance の克服を目指すには, 白血病の治療 のように, 腫瘍細胞を絶滅させるために初期治療を強化 するという手法が考えられる.膠芽腫では有効な薬剤が 1つしかないので, 多剤併用療法が適用できず, テモゾ ロミドの作用をいかに強くするか, という方向に行かざ るを得ない。この方向性に沿って, テモゾロミドの増量 療法や，その作用を増強させるという実験結果に基づい たインターフェロン併用療法が試みられたが，いずれも 効果はなく，この路線は行き詰まっている ${ }^{6) 177)}$.

もう 1 つの方向性は, 腫瘍幹細胞に特異的に作用する 治療を開発しようという試みで, 北中らはJNK 阻害剤を 使用することでグリオーマ幹細胞を制御する方法を提唱 している. 効果はどうか, 期待されるところである9).

テモゾロミドに対する抵抗性の獲得を理解するには, 腫瘍の不均一性（heterogeneity）と, テモゾロミドの薬 効メカニズム，という 2 つ観点が重要である.

膠芽腫に限らず, 多くの癌は数多くの異なる遺伝子異 常をもった腫瘍細胞の集合体であって, その多くは薬剤 に感受性があっても, ごく少数の細胞は, 薬剤の効果を 妨げる遺伝子異常をもっている可能性があり, それが結 果的に生き残って, 再発の原因になる。 ただ, この heterogeneity は現象としては理解できても, それを直接克 服する手段は今のところみえない.

一方，テモゾロミドの薬効からは克服の糸口が垣間み える、テモゾロミドはアルキル化剤で，グアニン塩基を メチル化し，これがミスマッチと認識されるために修復 酵素が㗢くが, メチル基のため修復ができず，結果的に 細胞死をもたらす。しかし, ミスマッチ修復遺伝子が不 活化されれば細胞は生き残ることになり，テモゾロミド 而性を獲得する ${ }^{12)}$. この現象は実際に再発神経膠腫で起 こっていることが確認されている。すすおわ，テモゾロ ミドを投与し続けることは, ミスマッチ修復遺伝子の機 能欠失細胞がより有利になる環境を与え続けていること になる。再発腫瘍におけるミスマッチ修復遺伝子の不活 化は，ゲノム全体で遺伝子複製の際のミスが修復されな いという状況を作り出し, その結果遺伝子変異の数が異 常に多い hypermutatorの出現につながることが判明し ている ${ }^{2)}$.このようなメカニズムで出現した再発腫瘍は 免疫原性が高くなっていることは他の癌種では知られて おり，膠芽腫においてもそのような性質がある可能性も ある。

細胞がテモゾロミドによるアルキル化を修復するもう 1 つの経路はアルキル化された塩基を切除して修復する 
メカニズムで，これには PARP 〔poly（ADP-ribose）polymerase〕という酵素の作用が必要である ${ }^{12)}$.この酵素が 阻害されればテモゾロミドによる細胞障害性を強化する ことになるので, 再発腫瘍の治療の 1 つの方向性として 検討がなされている.

\section{増殖抑制は可能か？}

膠芽腫がきわめて悪性である理由の 1 つは増殖の速さ にある，多くの膠芽腫は，発見されればすぐに治療され るので，自然経過をみることはほとんどなくなったが， まれにその経過がつかまることがある，わ机われも悪性 転化して膠芽腫になったと思われる腫瘍が，1 力月の間 にほとんど目に見えない状態から直径数 $\mathrm{cm}$ の腫瘤に なったのを経験したことがある。このように速い増殖 は，凄まじい勢いでの heterogeneity の獲得にもつなが り, 治療をいっそう困難にもする。近年癌の薬物療法で 目覚しい成果を挙げているチロシンキナーゼ阻害剤をは じめとするさまざまな分子標的薬は, 増殖シグナルを抑 えることにより腫瘍の発育速度を抑え，腫瘍の消退を誘 導するものである．膠芽腫に対して同様な効果を示す薬 剤があれば有効な治療となるはずである. The Cancer Genome Atlas で示された包括的な遺伝子解析からは, 膠 芽腫においては PIK3K の活性立進が必須の現象である ことが示されたが，そのメカニズムにはさまざまなパ ターンがあり，これまで行われた分子標的薬の治験で は，その活性を抑えて腫瘍の増殖を抑制し生命予後を改 善する, という結果は得られていない. その原因の 1 つ は，おそらくすでに腫瘍内の不均一性が著明で，単一の 分子を標的にした治療が全体に効果を及ぼせないか，新 たな遺伝子異常が次々に生まれるためにすぐに耐性を付 与する遺伝子異常が出現する，という状況だろう。もし 増殖抑制が可能になるとすれば，個々の腫瘍において増 殖に必須となっている，いわゆるドライバー遺伝子異常 が同定できて，それを制御するか，あるいは多数の分子 を一斉に複数の薬剤で標的とすることを狙うか，という 方法になると思われる。いずれの場合も，個々の腫瘍に おいてどのような分子メカニズムが腫瘍を成立させてい るかを判定しなくてはならず，これは現在推し進められ ている癌ゲノム医療の方向性と一致する。

\section{免疫療法の可能性}

本庶 佑先生のノーベル医学生理学賞もあり, その重 要性が脚光を浴びたのが, 癌免疫を操作する免疫療法で
ある、Nivolumab や pembrolizumab などの免疫チェクポ イント阻害剤は，癌細胞が獲得した免疫抑制機構を阻害 する薬剤で，さまざまな癌で有効性が示され，保険適応 になる癌種も拡大されてきた。しかし，再発や初発の膠 芽腫を対象とした臨床試験（CheckMate 試験）において は，効果は認められず，今のところ残念な結果になって いる ${ }^{10)}$. 脳では免疫担当細胞が他の組織に比べて到達し にくい組織であることがその原因なのか，あるいは膠芽 腫においては免疫原性の提示が著明でないのか，はっき りとした理由はまだわかっていない。一方で，免疫 チェックポイント阻害剤は，遺伝子変異の数が多い腫 瘍，すなわち tumor mutation burden の高い（TMB-high） 腫瘍においてより有效性が認められることがわかってお り，膠芽腫の中でもそのような腫瘍に絞った場合の有効 性の可能性は残っているかもしれない.

もう1つの可能性はウイルスを用いた免疫療法であ る. Duke 大学の Bigner らのグループは, 再発の膠芽腫 に対して改変型ポリオウイルスを局所注入して CD155 を強制発現させることによって免疫を活性化させるとい う，一種のワクチン療法を行つた結果，有望な結果が得 られたという報告を行った ${ }^{4)}$ 。また，東京大学医科学研 究所の藤堂らは, 腫瘍細胞の中だけで増殖して腫瘍細胞 を破壊するという改変型のヘルペスウイルス $(\mathrm{G} 47 \Delta)$ を，やはり局所投与する方法で再発膠芽腫の治療研究を 行っている。これも，破壊された腫瘍細胞が惹起する免 疫賦活作用が治療効果の重要な部分を担っており, “oncolytic immunotherapy”ということもできる．真の効 果は，これからまだ証明されていかなければならない が，治癒へ向かう可能性は示されている15).

\section{新たなパラダイムとしての TTF}

Tumor Treating Field（TTF）による電場療法は，まっ たく新たな治療パラダイムの治療機器で，第III相比較試 験で生命予後改善効果がみられたとして近年保険収載さ れた ${ }^{14)}$. 現在は phase IVの市販後調査が行われている が，少なくとも治癒を期待させるような効果は得られて いないようである．治療強度が十分でないのかもしれな い，これを強化できるのか，特に効果を示すようなサブ グループがあるのかどうか，など，今後の経験の蓄積を 元に何らかの改善を期待したい. 


\section{まとめ一「ゴルディアスの結び目」は 解けるか ?-}

膠芽腫が難治である理由は，浸潤性の腫瘍で，脳とい う特殊性からも完全摘出が不可能であること, 残存腫瘍 に対する術後治療の手段である放射線，化学療法に対す る抵抗性があり, 完全に腫瘍を殺すことができないこ と, が 2 つ大きな理由である. 加えて, 高い増殖性と 腫瘍内の不均一性は, 課題をさらに困難にしている。や はり外科手術の限界は明らかで, 治癒を目指すには, もつと有効な術後の治療を開発するしかない.

「ゴルディアスの結び目」の伝説をご存知だろうか？ 古代アナトリア（現在のトルコの辺り）にあったフリギ アという王国の都の神殿には，かつての王ゴルディアス が残した，柱と牛車の轅をくくりつけた複雑な結び目が あって，「この結び目を解くことができた者はアジアの 王になる」という予言があった，何百年も解くことがで きずにいたところに，遠征中のアレクサンドロス大王が 訪れ，これを解こうとしたが，やはりあれこれやっても うまくいかない，すると大王はおもむろに自分の剣を持 ち出して, 一刀両断, 結び目を断ち切ってしまった。 そ の途端に雷鳴が轟いて，予言どおり，アレクサンドロス がアジアの王になった，という話である。以来，「ゴル ディアスの結び目」は解けない難問，の意味で用いられ ている．膠芽腫の治癒も今のところなかなか解けそうな 問題にはみえないが，これを解くためには，やはり地道 にいろいろ引っ張ってはほどこうとする努力を続ける, という方向と, 誰も思いつかなかったような新たなパラ ダイムの治療法で一刀両断, という方向があるのかもし れない. ただ，いつかは解ける，というのが信念であり， 希望でもある。

著者は日本脳神経外科学会への COI 自己申告の登録を完了 しています。

本論文に関して開示すべき COI はありません。

\section{文 献}

1) Cancer Genome Atlas Research Network, Brat DJ, Verhaak RG, Aldape KD, Yung WK, Salama SR, Cooper LA, Rheinbay E, Miller CR, Vitucci M, Morozova O, Robertson AG, Noushmehr H, Laird PW, Cherniack AD, Akbani R, Huse JT, Ciriello G, Poisson LM, Barnholtz-Sloan JS, Berger MS, Brennan C, Colen RR, Colman H, Flanders AE, Giannini C, Grifford M, Iavarone A, Jain R, Joseph I, Kim J, Kasaian K, Mikkelsen T, Murray BA, O'Neill BP, Pachter L, Parsons DW, Sougnez C, Sulman EP, Vandenberg SR, Van Meir EG, von Deimling A, Zhang H, Crain D, Lau K, Mallery D, Morris S, Paulauskis J, Penny R, Shelton T, Sherman M, Yena P, Black A, Bowen J, Dicostanzo K, Gastier-Foster J, Leraas KM, Lichtenberg TM, Pierson CR, Ramirez NC, Taylor C, Weaver S, Wise L, Zmuda E, Davidsen T, Demchok JA, Eley G, Ferguson ML, Hutter CM, Mills Shaw KR, Ozenberger BA, Sheth M, Sofia HJ, Tarnuzzer R, Wang Z, Yang L, Zenklusen JC, Ayala B, Baboud J, Chudamani S, Jensen MA, Liu J, Pihl T, Raman R, Wan Y, Wu Y, Ally A, Auman JT, Balasundaram M, Balu S, Baylin SB, Beroukhim R, Bootwalla MS, Bowlby R, Bristow CA, Brooks D, Butterfield Y, Carlsen R, Carter S, Chin L, Chu A, Chuah E, Cibulskis K, Clarke A, Coetzee SG, Dhalla N, Fennell T, Fisher S, Gabriel S, Getz G, Gibbs R, Guin R, Hadjipanayis A, Hayes DN, Hinoue T, Hoadley K, Holt RA, Hoyle AP, Jefferys SR, Jones S, Jones CD, Kucherlapati R, Lai PH, Lander E, Lee S, Lichtenstein L, Ma Y, Maglinte DT, Mahadeshwar HS, Marra MA, Mayo M, Meng S, Meyerson ML, Mieczkowski PA, Moore RA, Mose LE, Mungall AJ, Pantazi A, Parfenov M, Park PJ, Parker JS, Perou CM, Protopopov A, Ren X, Roach J, Sabedot TS, Schein J, Schumacher SE, Seidman JG, Seth S, Shen H, Simons JV, Sipahimalani P, Soloway MG, Song X, Sun H, Tabak B, Tam A, Tan D, Tang J, Thiessen N, Triche T Jr, Van Den Berg DJ, Veluvolu U, Waring S, Weisenberger DJ, Wilkerson MD, Wong T, Wu J, Xi L, Xu AW, Yang L, Zack TI, Zhang J, Aksoy BA, Arachchi H, Benz C, Bernard B, Carlin D, Cho J, DiCara D, Frazer S, Fuller GN, Gao J, Gehlenborg N, Haussler D, Heiman DI, Iype L, Jacobsen A, Ju Z, Katzman S, Kim H, Knijnenburg T, Kreisberg RB, Lawrence MS, Lee W, Leinonen K, Lin P, Ling S, Liu W, Liu Y, Liu Y, Lu Y, Mills G, Ng S, Noble MS, Paull E, Rao A, Reynolds S, Saksena G, Sanborn Z, Sander C, Schultz N, Senbabaoglu Y, Shen R, Shmulevich I, Sinha R, Stuart J, Sumer SO, Sun Y, Tasman N, Taylor BS, Voet D, Weinhold N, Weinstein JN, Yang D, Yoshihara K, Zheng S, Zhang W, Zou L, Abel T, Sadeghi S, Cohen ML, Eschbacher J, Hattab EM, Raghunathan A, Schniederjan MJ, Aziz D, Barnett G, Barrett W, Bigner DD, Boice L, Brewer C, Calatozzolo C, Campos B, Carlotti CG Jr, Chan TA, Cuppini L, Curley E, Cuzzubbo S, Devine K, DiMeco F, Duell R, Elder JB, Fehrenbach A, Finocchiaro G, Friedman W, Fulop J, Gardner J, Hermes B, Herold-Mende C, Jungk C, Kendler A, Lehman NL, Lipp E, Liu O, Mandt R, McGraw M, Mclendon R, McPherson C, Neder L, Nguyen P, Noss A, Nunziata R, Ostrom QT, Palmer C, Perin A, Pollo B, Potapov A, Potapova O, Rathmell WK, Rotin D, Scarpace L, Schilero C, Senecal K, Shimmel K, Shurkhay V, Sifri S, Singh R, Sloan AE, Smolenski K, Staugaitis SM, Steele R, Thorne L, Tirapelli DP, Unterberg A, Vallurupalli M, Wang Y, Warnick R, Williams F, Wolinsky Y, Bell S, Rosenberg M, Stewart C, Huang F, Grimsby JL, Radenbaugh AJ, Zhang J: Comprehensive, integrative genomic analysis of diffuse lower-grade gliomas. $N$ Engl J Med 372:2481-2498, 2015.

2) Choi S, Yu Y, Grimmer MR, Wahl M, Chang SM, Costello JF : Temozolomide-associated hypermutation in gliomas. Neuro Oncol 20 : 1300-1309, 2018.

3) Dandy WE : Removal of right cerebral hemisphere for certain tumors with hemiplegia: Preliminary report. JAMA 90: 823-825, 1925.

4) Desjardins A, Gromeier M, Herndon JE 2nd, Beaubier N, Bolognesi DP, Friedman AH, Friedman HS, McSherry F, Muscat AM, Nair S, Peters KB, Randazzo D, Sampson JH, 
Vlahovic G, Harrison WT, McLendon RE, Ashley D, Bigner DD : Recurrent glioblastoma treated with recombinant poliovirus. NEngl J Med 379: 150-161, 2018.

5) Gardner WJ : Removal of the right cerebral hemisphere for infiltrating glioma - report of a case. JAMA 101:823-826, 1933.

6) Gilbert MR, Wang M, Aldape KD, Stupp R, Hegi ME, Jaeckle KA, Armstrong TS, Wefel JS, Won M, Blumenthal DT, Mahajan A, Schultz CJ, Erridge S, Baumert B, Hopkins KI, Tzuk-Shina T, Brown PD, Chakravarti A, Curran WJ Jr, Mehta MP : Dose-dense temozolomide for newly diagnosed glioblastoma : a randomized phase III clinical trial. J Clin Oncol 31:4085-4091, 2013.

7) Matsukado Y, Maccarty CS, Kernohan JW : The growth of glioblastoma multiforme (astrocytomas, grades 3 and 4) in neurosurgical practice. J Neurosurg 18:636-644, 1961.

8) Miyatake SI, Kawabata S, Hiramatsu R, Kuroiwa T, Suzuki $\mathrm{M}$, Ono K : Boron neutron capture therapy of malignant gliomas. Prog Neurol Surg 32: 48-56, 2018.

9) Okada M, Kuramoto K, Takeda H, Watarai H, Sakaki H, Seino S, Seino M, Suzuki S, Kitanaka C: The novel JNK inhibitor AS602801 inhibits cancer stem cells in vitro and in vivo. Oncotarget $7: 27021-27032,2016$.

10) Omuro A, Vlahovic G, Lim M, Sahebjam S, Baehring J, Cloughesy T, Voloschin A, Ramkissoon SH, Ligon KL, Latek R, Zwirtes R, Strauss L, Paliwal P, Harbison CT, Reardon DA, Sampson JH : Nivolumab with or without ipilimumab in patients with recurrent glioblastoma : results from exploratory phase I cohorts of CheckMate 143. Neuro Oncol $20: 674-686,2018$.

11) Sanai N, Polley MY, McDermott MW, Parsa AT, Berger MS : An extent of resection threshold for newly diagnosed glioblastomas. J Neurosurg $115: 3-8,2011$.

12) Sarkaria JN, Kitange GJ, James CD, Plummer R, Calvert H, Weller M, Wick W: Mechanisms of chemoresistance to alkylating agents in malignant glioma. Clin Cancer Res 14:2900-2908, 2008.

13) Schiffer D, Annovazzi L, Casalone C, Corona C, Mellai M : Glioblastoma : Microenvironment and niche concept. Cancers (Basel) 11, 2018.

14) Stupp R, Taillibert S, Kanner A, Read W, Steinberg D, Lhermitte B, Toms S, Idbaih A, Ahluwalia MS, Fink K, Di Meco F, Lieberman F, Zhu JJ, Stragliotto G, Tran D, Brem S, Hottinger A, Kirson ED, Lavy-Shahaf G, Weinberg U, Kim CY, Paek SH, Nicholas G, Bruna J, Hirte H, Weller M, Palti Y, Hegi ME, Ram Z : Effect of tumor-treating fields plus maintenance temozolomide vs maintenance temozolomide alone on survival in patients with glioblastoma: A randomized clinical trial. JAMA 318:2306-2316, 2017.

15) Taguchi $S$, Fukuhara $H$, Todo $T$ : Oncolytic virus therapy in Japan : progress in clinical trials and future perspectives. Jpn J Clin Oncol 49 : 201-209, 2019.

16) Tanaka $M$, Ino $Y$, Nakagawa $K$, Tago $M$, Todo $T$ : High-dose conformal radiotherapy for supratentorial malignant glioma : a historical comparison. Lancet Oncol $\quad 6$ : 953-960, 2005.

17) Wakabayashi T, Natsume A, Mizusawa J, Katayama H, Fukuda H, Sumi M, Nishikawa R, Narita Y, Muragaki Y, Maruyama T, Ito T, Beppu T, Nakamura H, Kayama T, Sato S, Nagane M, Mishima K, Nakasu Y, Kurisu K, Yamasaki F, Sugiyama K, Onishi T, Iwadate Y, Terasaki M, Kobayashi H, Matsumura A, Ishikawa E, Sasaki H, Mukasa A, Matsuo T, Hirano H, Kumabe T, Shinoura N, Hashimoto N, Aoki T, Asai A, Abe T, Yoshino A, Arakawa Y, Asano K, Yoshimoto K, Shibui S ; Members of Japan Clinical Oncology Group Brain Tumor Study Group (JCOG-BTSG) : JCOG0911 INTEGRA study : a randomized screening phase II trial of interferonbeta plus temozolomide in comparison with temozolomide alone for newly diagnosed glioblastoma. $\mathrm{J} \mathrm{Neu}$ rooncol 138:627-636, 2018.

過去数十年にわたる癌研究の成果は, 近年やっとその成果をもたらしつつあり, さまざまな癌の生 存期間が延び, 中には治癒が期待できるものも出てきた. 一方, 脳腫瘍の中でも頻度の高い膠芽腫の 予後はあまり昔と変わっていない，という辛い指摘がある. それはなぜなのかをもう一度腰を落ち着 けて, 分析的に考察し, これからの取り組みに反映させることは意味がありそうである. あらゆる癌 の中で膠芽腫の死亡率が最も高い理由は, 脳にあること, 浸潤性が高いこと, 放射線治療や化学療法 に対する抵抗性が高いこと, 増殖が速いこと, 免疫系の活動が乏しいこと, などが挙げられよう.こ れらを解決する糸口としては, 地道な研究の継続と, まったく新たな治療パラダイムの開発という 2 つの側面からのアプローチが続けられることが必要だろう. 